\title{
V. RELIGION AND PHILOSOPHY.
}

The American Philosophy, Pragmatism, Critically Consldered In Relation to Present-Day Theology. By A. v. C. P. Huitzinga, author of "Belief in a Personal God," "Discussions on Damnation," etc. Boston. 1911. Sherman, French \& Company. 64 pages. 60 cents net.

Vigorously, boldly, does the author of this volume present and attack the fundamental temper, method and claims of that Pragmatic school of thinkers just now making so much noise in the sphere of philosophy. Out of a wealth of reading and reflection Mr. Huitzinga is able to produce reasons and arguments against every essential feature of Pragmatism. He rightly evaluates its positions by appealing to their connection with the democratic individualism of our time and country, the evolutionary principle in science, the practical temper of a materially progressive age, and a theological situation dominated by the Ritschlian distinction between value-judgment and existencejudgment.

The author makes such extensive use of other writers, quotes from them with such frequency and extent, and so frequently turns aside for some comment on a collateral issue thus introduced as to interfere somewhat with the continuity and orderliness of his discussion. One also rather suspects that a good many readers will fail of full appreciation of the numerous Latin, Greek, German and French terms, phrases and quotations. But for the quite obvious earnestness and simplicity of purpose there would be a suggestion of pedantry.

W. O. Carver.

Great Religlous Teachers of the East. By Alfred W. Martin, Associate Leader of the Society for Ethical Culture in New York. New York. 1911. The Macmillan Company. 268 pages. \$1.25 net.

Here we have seven of a course of twelve lectures delivered early in 1911 " at the Meeting-House of the Society for Ethical Culture of New York." The first deals with "The Discovery of the Sacred Books of the East and Its Results." Number five 
has for its subject, "The Prophets of Israel and the Commonwealth of Man." The others treat Gotama, the Buddha; Zoroaster; Confucius and Lao-Tze; Jesus; and Mohammed.

With a free hand and full confidence in his own ideas this author sketches the careers, very summarily, and the teaching and the influence of these great leaders. He is careful to rap Christianity upon occasion and in the midst of his discussion of Jesus,-a very appreciative discussion it is, with real insight,he turns about to express dissent from Jesus' teaching "with reference to marriage, divorce, wealth, intellectual and aesthetic pursuits." This he does, not to tell us wherein Jesus is in error, but apparently just to season his inevitable praise of Jesus with a superior criticism. He misses the mark when he defines the "special life-purpose of Jesus" as "to prepare the largest possible number of men and women for membership in the new kingdom of Heaven." Otherwise he shows his inability to reach up to the comprehension of Jesus. His bibliography indicates a choice of literature largely of a certain critical type.

The style is easy and lucid and the whole moves in a realm of ethical thought of a high order.

W. O. Carver.

Aspects of Islam. By Duncan Black Macdonald, M.A., D.D., sometime Scholar and Fellow of the University of Glasgow; Professor of Semitic Languages in Hartford Theological Seminary; Author of Development of Muslim Theology, Jurisprudence and Constitutional Theory; The Religious Attitude and Life in Islam, etc. New York, 1911. The Macmillan Company. $x i+375$ pages. $\$ 1.50$ net.

This volume is the third of the Hartford-Lamson Lectures to be published. The series, beginning with an "Introduction to the Study of Comparative Religion," by Principal Jevons and followed up by De Groot's "Religion of the Chinese", is adhering to the ideal of an introductory course suited to the needs of prospective missionaries and other elementary students of religion. At the same time it will be recognized at once that the selection of saholars of the first class in this department gives a 